\title{
Pemodelan Sebaran Habitat Dugong Dugon Kawasan Pesisir Pulau Bintan Kepulauan Riau, Indonesia
}

\author{
Zaki Mubarok ${ }^{1}$, Rizki Atthoriq Hidayat ${ }^{2}$, Ahyuni ${ }^{3}$, Luhur Moekti Prayogo ${ }^{4}$ dan \\ Hendra Saputra ${ }^{5}$ \\ ${ }^{1,2}$ Program Studi Geografi, Universitas Negeri Padang \\ ${ }^{3}$ Pasca-Sarjana Universitas Negeri Padang \\ ${ }^{4}$ Fakultas Perikanan dan Kelautan, Universitas PGRI Ronggolawe \\ ${ }^{5}$ Program Studi Pendidikan Geografi, Universitas Islam Negeri Sultan Syarif Kasim Riau \\ e-mail: zakidafa14@gmail.com, rizkiatthoriq99@gmail.com
}

\begin{abstract}
ABSTRAK. Dugong adalah mamalia laut milik Sirenia dengan nama ilmiah Dugong Dugon atau sering juga disebut sebagai sapi laut yang berstatus hukum sebagai hewan yang dilindungi di Indonesia. Di Pulau Bintan kasus penemuan dugong sering terjadi. Kondisi ekosistem perairan dengan hamparan vegetasi lamun mendukung kelangsungan hidup mamalia herbivora seperti Dugong. Tujuan dari penelitian ini adalah melakukan pemodelan spasial untuk mengetahui sebaran habitat dugong dengan menggunakan beberapa variabel lingkungan yang terjadi di ekosistem laut yang menjadi indikator penilaian penunjang keberlangsungan hidup dugong. Metode yang digunakan adalah analisis spasial raster untuk perancangan variabel lingkungan yang meliputi naturalized Euclidean distance, dan Maximum Entropy. Berdasarkan hasil kajian, nilai AUC pemodelan adalah 0.96 dengan nilai deviasi 0.04 , sedangkan distribusi wilayah yang berpotensi untuk sebaran habitat dugong di beberapa perairan Pulau Bintan yaitu Desa Berakit, Gunung Kijang, Kawal, dan Malang Temu. Parameter yang paling berpengaruh dalam pemodelan sebaran potensi habitat dugong ini adalah padang lamun, jarak dari sungai, dan kedalaman laut. Habitat yang sangat mendukung kehidupan dugong ini didominasi oleh vegetasi tutupan lamun yang merupakan sumber makanan utama dugong.
\end{abstract}

Kata kunci: pemodelan spasial, dugong, habitat, ekosistem

\section{PENDAHULUAN}

Dugong (Dugong dugon) termasuk dalam kelas mamalia laut yang bercirikan hewan yang menyusui anaknya tergolong sebagai Ordo Sirenia, yang mana dicirikan bersifat herbivora (Muller 1976). Dugong dewasa jarang melebihi panjang 3 meter dan beratnya mencapai sekitar $420 \mathrm{~kg}$. Habitat dugong adalah daerah pesisir di perairan dangkal sampai sedang sekitar 20 meter di bawah permukaan laut. Hewan ini sering bermigrasi ketika terjadi perubahan curah hujan. Sebagian besar aktivitas sehari-hari dugong adalah mencari makan diperairan dangkal. Selain memiliki kehidupan sosial, dugong juga memiliki kebiasaan muncul ke permukaan air (surfacing), menggelinding (rolling), dan istirahat (resting). Kondisi ekosistem yang paling cocok untuk dugong ini adalah ekosistem lamun di iklim tropis dan subtropis. Dugong sendiri termasuk salah satu hewan langka di Indonesia. Kementerian Kelautan dan Perikanan (KKP) telah memasukkan dugong sebagai salah satu dari 20 spesies prioritas. Dugong juga dilindungi sepenuhnya dalam UU no. 5 Tahun 1990 tentang Konservasi Sumber Daya Alam Hayati dan Ekosistemnya serta UU No. 31 Tahun 2004 tentang Perikanan. Di Indonesia, konservasi dugong telah dilakukan sejak tahun 2016 oleh United Nation Environment Program-Conservation Migratory Species (UNEP-CMS), Mohamed bin Zayed Species Conservation Fund (MbZ) bersama Kementerian Kelautan dan Perikanan, LIPI, WWF Indonesia, dan IPB, melalui programnya Dugong and Seagrass Conservation Project (DSCP). Namun upaya konservasi yang dilakukan masih menghadapi berbagai macam kendala seperti keterbatasan pengetahuan tentang padang lamun 
sehingga banyak yang mengalami kerusakan dan degradasi padang lamun. Dan juga kematian dugong akibat aktivitas (bycatch) dan perburuan oleh masyarakat setempat (KKP, 2016).

Kabupaten Bintan merupakan salah satu daerah yang memiliki ekosistem perairan yang masih terjaga kelestariannya, terbukti keberadaan dugong masih sering dijumpai di perairan tersebut. Namun, beberapa kali hewan ini tertangkap secara tidak sengaja atau terdampar di kawasan sekitar Pulau Bintan. Hal ini menjadi daya tarik tersendiri bagi wisatawan untuk berkunjung ke Pulau Bintan. Selain memiliki fitur alam yang melimpah, perairan Pulau Bintan juga dikenal sebagai salah satu habitat dugong di Indonesia. Keberadaan dugong di perairan Pulau Bintan dan sekitarnya telah lama menjadi bagian yang tidak terpisahkan dari kehidupan masyarakat di Provinsi Kepulauan Riau, sehingga dugong sendiri telah menjadi icon pariwisata di Kabupaten Bintan (Ambari, 2018). Dari waktu ke waktu, minat masyarakat terhadap hewan laut ini semakin meningkat, tidak hanya sebagai objek wisata, dugong juga diburu dan dikonsumsi (DSCP Indonesia, 2018 dan Siti, 2018). Ancaman yang sering terjadi adalah penggunaan jaring ikan yang biasa ditebarkan oleh nelayan di satu blok wilayah perairan kemudian dibiarkan selama hampir 24 jam. Kondisi ini dapat membuat dugong terjerat jaring (Ati, 2018).

Dinamika kawasan ekosistem pesisir perlu menjadi perhatian penting dalam berbagai tujuan, dan pemantauan kondisi ekosistem pesisir dengan pemanfaatan teknologi geospasial seperti penginderaan jauh, sistem informasi geografis yang dipadukan dengan spasial data sains seperti maximum entropy, ini sangat berguna dan penting dalam integrasi data geospasial untuk pengelolaan kawasan lindung serta konservasi habitat satwa liar (Hanif, et al. 2021a, 2021b). Untuk menentukan sebaran sebaran dugong perlu dilakukan pengolahan data spasial karena terdapat berbagai indikator geografis dan lingkungan yang memberikan informasi spasial tematik mengenai hal tersebut. Maka, tujuan dari penelitian ini adalah melakukan pemodelan spasial untuk mengetahui sebaran habitat dugong dengan menggunakan beberapa variabel lingkungan yang terjadi di ekosistem laut yang menjadi indikator penilaian penunjang keberlangsungan hidup dugong.

Lokasi penelitian ini adalah sebagian Pulau Bintan merupakan salah satu pulau yang berada di Provinsi Kepulauan Riau, dimana terdapat Kota Tanjung Pinang, Ibu Kota Provinsi Kepulauan Riau. Pulau ini dikenal memiliki keindahan alam dan ekosistem perairan yang beragam, didominasi oleh hutan mangrove, lamun, terumbu karang di Pulau Bintan juga merupakan salah satu ekosistem subur yang terdapat di sekitar pantai.

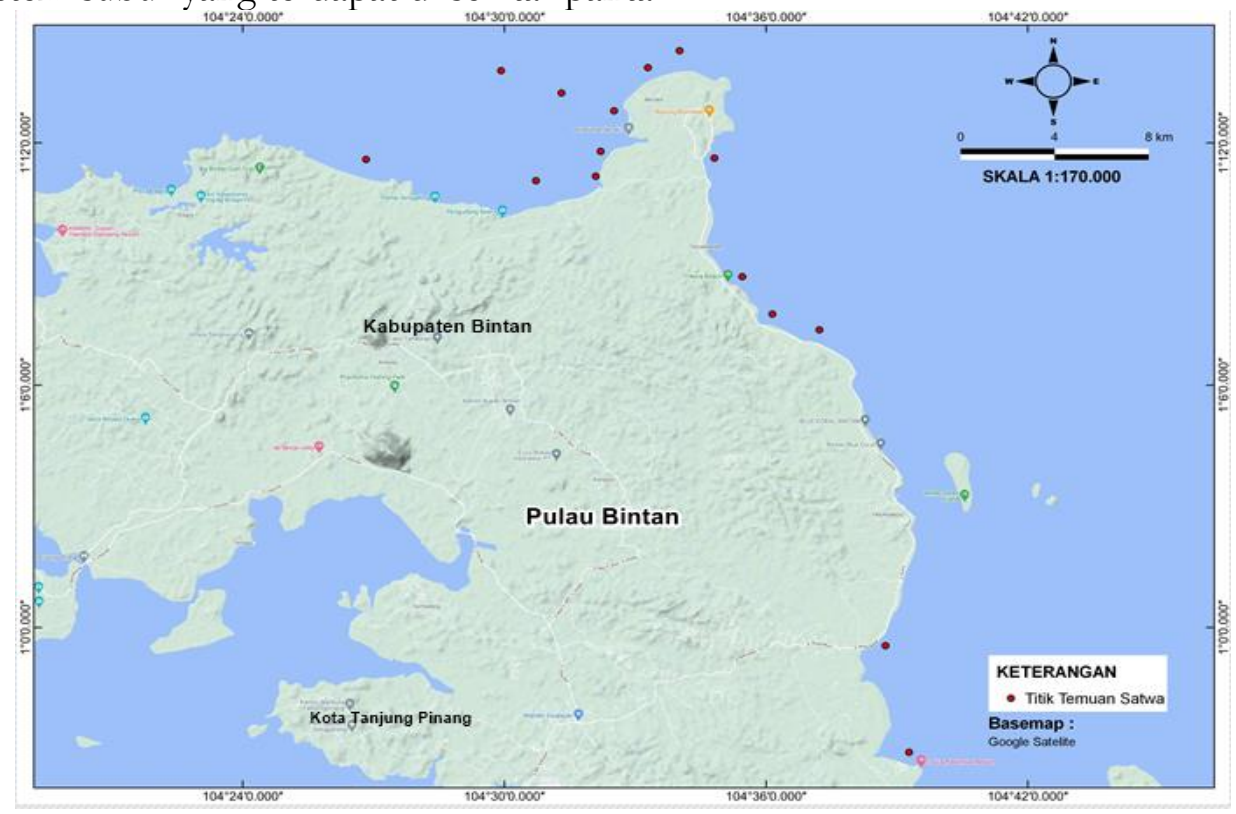

Gambar 1. Lokasi penelitian di pesisir Pulau Bintan dan sebaran titik dugong yang ditemukan 


\section{METODE}

\subsection{Data}

Data yang digunakan dalam penelitian ini adalah citra digital yang diperoleh dari United States Geological Surveys (USGS) yang dapat diakses secara gratis di http://earthwxplorer.usgs.gov yaitu citra Landsat 8 OLI dengan akurasi 30x30 meter. Citra Landsat 8 OLI digunakan untuk klasifikasi tutupan lahan di perairan Pulau Bintan berupa vegetasi perairan (lamun) di sekitar kawasan. Analisis kejernihan air atau total suspended solid (TSS) juga diperoleh dari pengolahan citra Landsat 8 Oli menggunakan Band 4 pada citra Landsat. Data citra batrimetri digunakan untuk menganalisis morfologi pantai untuk mengetahui jenis pantai di sekitar perairan Pulau Bintan. Titik temuan dugong diperoleh dari dokumen IUCN, KKP dan LIPI. Dalam penelitian ini juga dilakukan survei lapangan oleh tim peneliti pada tahun 2020 dan dokumentasi untuk memperkuat hasil penelitian dengan membuktikan sebaran vegetasi lamun yang menjadi sumber makanan bagi dugong.

\subsection{Metode Analisis}

\subsubsection{Desain Variabel Lingkungan}

Data spasial merupakan salah satu elemen penting yang menjadi landasan dalam melakukan dan mendukung berbagai kegiatan, salah satunya adalah persebaran habitat atau spesies. Pemodelan dengan maximum entropy atau Maxent berpotensi untuk mengidentifikasi distribusi dan pemilihan habitat satwa liar dengan pertimbangan tergantung pada lokasi keberadaannya (Baldwin, 2009). Pemodelan maximum entropy dilakukan dengan menggunakan beberapa set data spasial sebagai variabel lingkungan dan titik pertemuan sebagai data yang ada, sehingga perangkat lunak ini mampu melakukan probabilitas distribusi spesifik spesies sesuai dengan kondisi lingkungan. Dalam hal ini, pemodelan Maxent digunakan untuk penerapannya pada sebaran sebaran habitat dugong di beberapa perairan Pulau Bintan. Beberapa set data lingkungan yang digunakan dalam pemodelan Maxent, yaitu (1) lamun, terumbu karang (polip) (2) jarak sungai, (3) kedalaman air, (4) kecerahan air.

\subsubsection{Tahapan Pengolahan Data Variabel Lingkungan}

Tahapan pengolahan pembuatan data variabel lingkungan dilakukan dengan beberapa proses. (1) klasifikasi citra satelit dengan teknik klasifikasi terbimbing ini dilakukan untuk pembuatan peta ekosistem padang lamun dan terumbu karang (2) analisis transformasi citra dengan model total sedimen tersuspensi TSS, hal ini dilakukan untuk memetakan tingkat kekeruhan perairan. perairan, karena salah satu variabel lingkungan dalam pemodelan habitat dugong adalah kualitas kebersihannya. (3) Analisis jarak euclidean, hal ini dilakukan untuk membuat peta variabel lingkungan jarak sungai dengan lingkungan sekitarnya. (4) reklasifikasi adalah proses pengelompokan data batimetri untuk membagi interval kedalaman perairan sebagai salah satu variabel lingkungan.

\subsubsection{Pemodelan Habitat dengan Maximum Entropy (Maxent)}

Untuk pemodelan habitat banyak metode yang dapat digunakan, dalam beberapa kasus peneliti konservasi lebih popular menggunakan teknologi sekaligus pergangkat komputasi untuk prediksi sebaran ataupun distribusi satwa dengan mode maximum entropy (Hidayat, 2020). Pada proses maximum entropy, akan ada dua pilihan data, (1) menyajikan data dan (2) variabel lingkungan. Untuk input data preset (Abbas, 2017). Data yang akan digunakan adalah koordinat X dan Y sebaran dugong, satuan dari sistem koordinat ini adalah dalam meter. Kemudian untuk variabel lingkungan, data yang dimasukkan adalah semua data variabel lingkungan yang telah diolah pada tahap sebelumnya yaitu, (a) lamun, terumbu karang (polip) (b) jarak sungai, (c) kedalaman perairan, (d) kecerahan air. Perlu dicatat bahwa dalam analisis maksimal ini, variabel lingkungan perlu dipertimbangkan sebagai data kategorikal atau data kontinu. Semua sistem proyeksi 
koordinat peta data variabel lingkungan harus sama. Ukuran piksel data juga harus sama, dan semua data harus bertipe file (asci).

Pemodelan maximum entropy akan memberikan hasil prediksi dalam nilai statistik (Baldwin, 2009 dan Philips, 2008). Hasil akhir dari perhitungan model dari Maxent adalah logistik yang digunakan untuk menginterpretasikan dan membaca output dari model ini, yang berkisar antara 0 sampai 1 , dimana 1 adalah probabilitas tertinggi dan sesuai dengan data dan variabel prediktor yang ada (Baldwin, 2009 dan Abidin, 2019). Keluaran dari maximum entropy berisi informasi penting salah satunya adalah area under the curve (AUC), yang melaporkan kinerja variabel dan persentase kontribusi variabel (Nazeri, 2012 dan Abidin, 2019). Kisaran nilai AUC adalah dari 0,5 hingga 1,1. Sebagai kesimpulan dari model ini, kinerja AUC akan dibagi menjadi tiga interval: di bawah 0,7 adalah kinerja model yang buruk, 0,7 hingga 0,9 adalah kinerja sedang, dan di atas 0,9 adalah kinerja yang sangat baik (Gunawan, 2013).

\section{HASIL DAN PEMBAHASAN}

\section{Hasil}

Sebaran habitat potensial dugong merupakan hasil perhitungan statistik dengan menggunakan algoritma Maximum Entrophy (Maxent), dimana entropi adalah selisih atau diversitas, hal ini sangat tepat digunakan untuk menghitung heterogenitas data dalam satu himpunan, dimana kumpulan data disini adalah variabel lingkungan. Desain data awal Maxent dilakukan dengan alat sistem informasi geografis. Hasil pemodelan ini diperoleh kurva karakteristik operasi penerima (ROC) untuk data yang dengan informasi sama, dilakukan perhitungan rata-rata selama pengulangan model berlangsung. Perhatikan bahwa spesifisitas ditentukan menggunakan area yang diprediksi, daripada komisi yang sebenarnya. Rata-rata AUC tes untuk pengulangan berjalan adalah 0,96 , dan standar deviasinya adalah 0,04 .

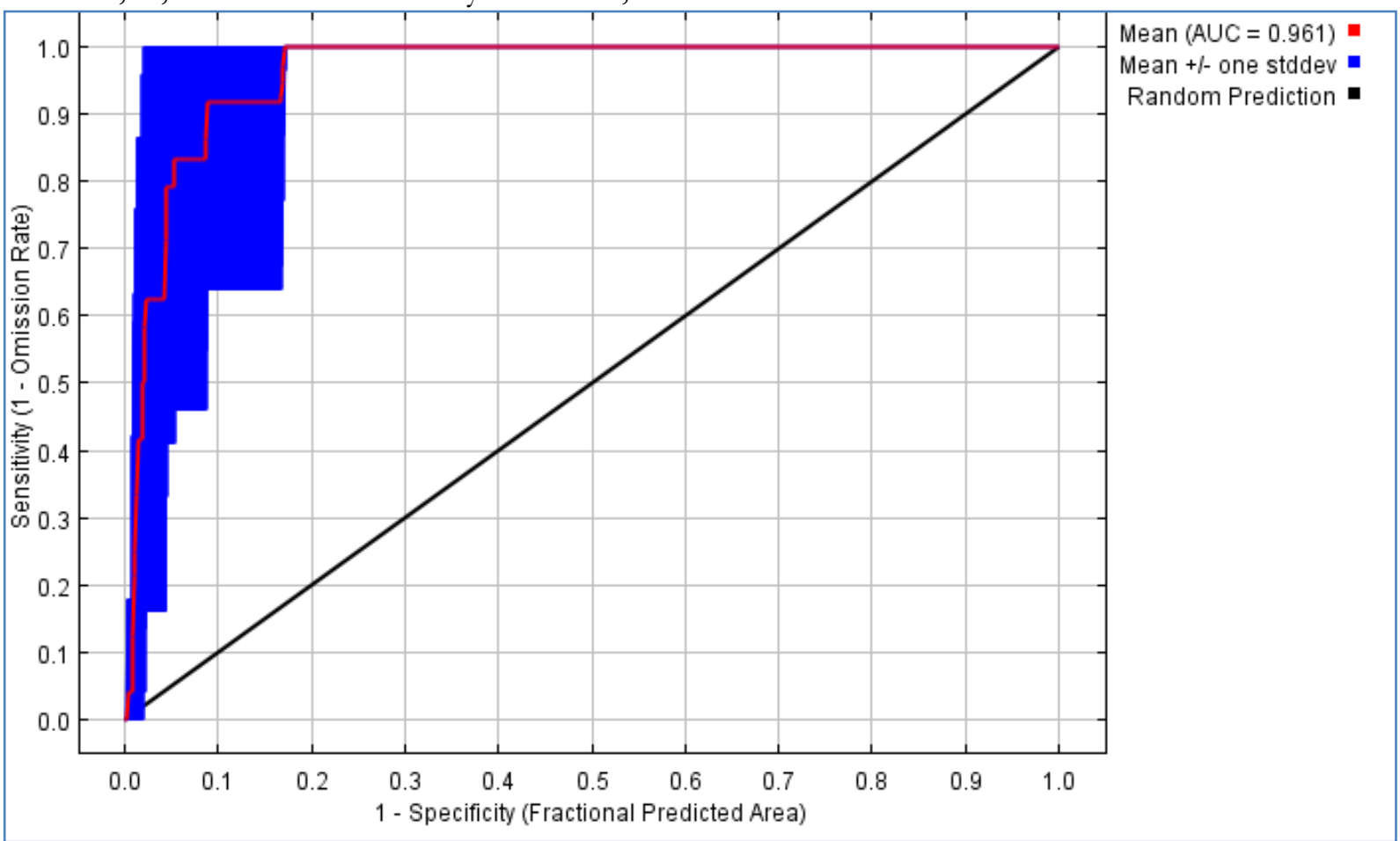

Gambar 2. Kurva AUC Area Under the Curvae Hasil Pemodelan 
01-kedalaman-kelas

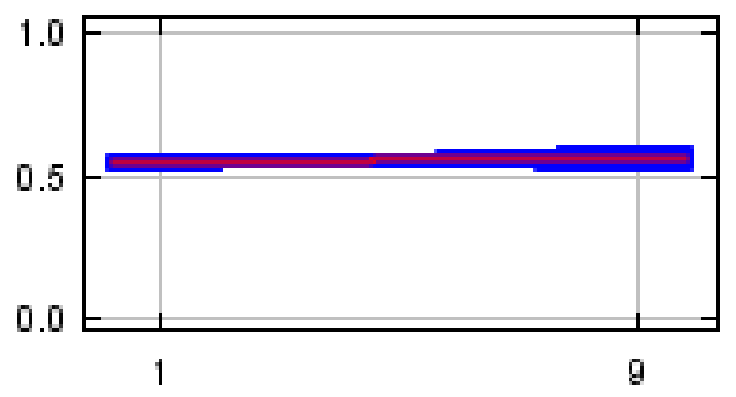

03-jarak-sungai

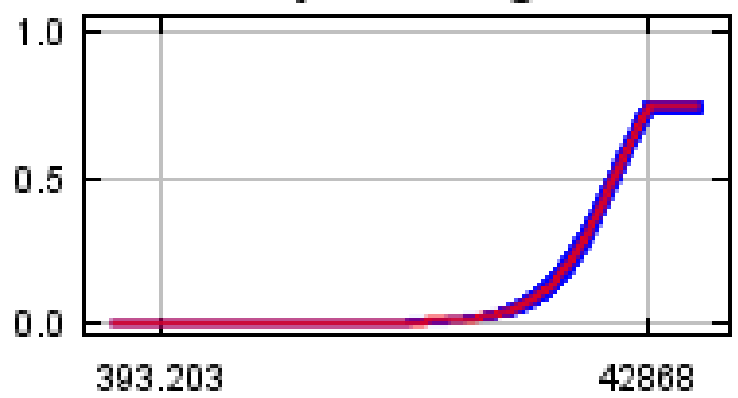

02-padang-lamun

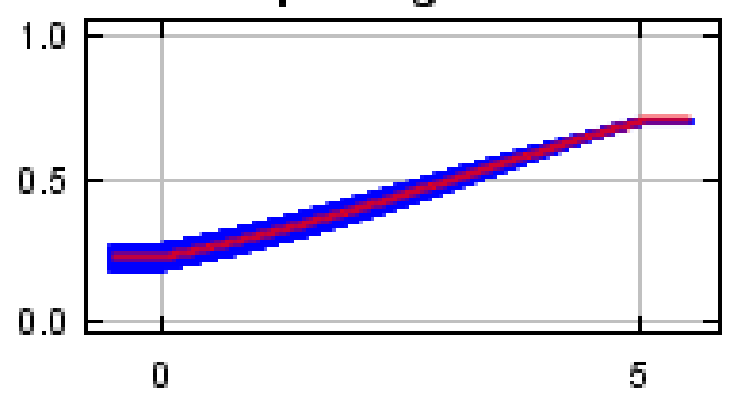

04-kecerahan-perairan

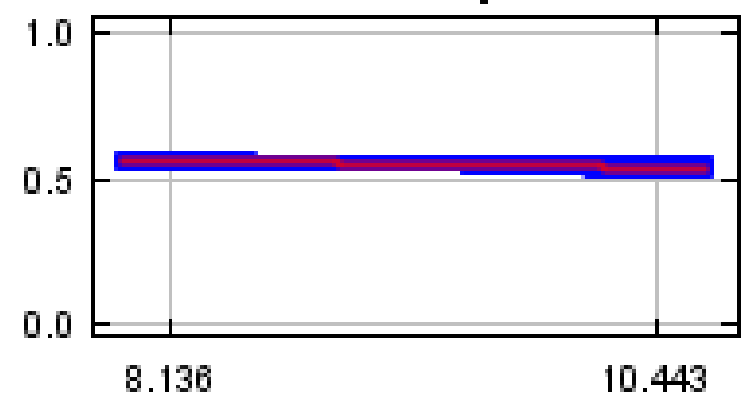

Gambar 3. Kurva Respon Masing-Masing Variabel Pemodelan Terhadap Hasil Prediksi

Kurva ini menunjukkan bagaimana setiap variabel lingkungan mempengaruhi prediksi Maxent. Kurva menunjukkan bagaimana kemungkinan prediksi kehadiran sebuah kemungkinan berubah karena setiap variabel lingkungan bervariasi dalam memberikan pengaruh, menjaga pengaruh semua variabel lingkungan lainnya pada nilai sampel rata-rata pemodelan. Perhatikan bahwa kurva mungkin sulit untuk ditafsirkan jika Anda memiliki variabel yang berkorelasi kuat, karena model mungkin bergantung pada korelasi dengan cara yang tidak terlihat dalam kurva. Dengan kata lain, kurva menunjukkan efek marginal dari perubahan tepat satu variabel, sedangkan model dapat mengambil keuntungan dari sekumpulan variabel yang berubah bersama-sama. Kurva menunjukkan respon rata-rata dari 12 ulangan model Maxent, dengan keterangannya dimana Maxent run (merah) dan dan rata-rata +/- satu standar deviasi (biru, dua warna untuk variabel kategori). 

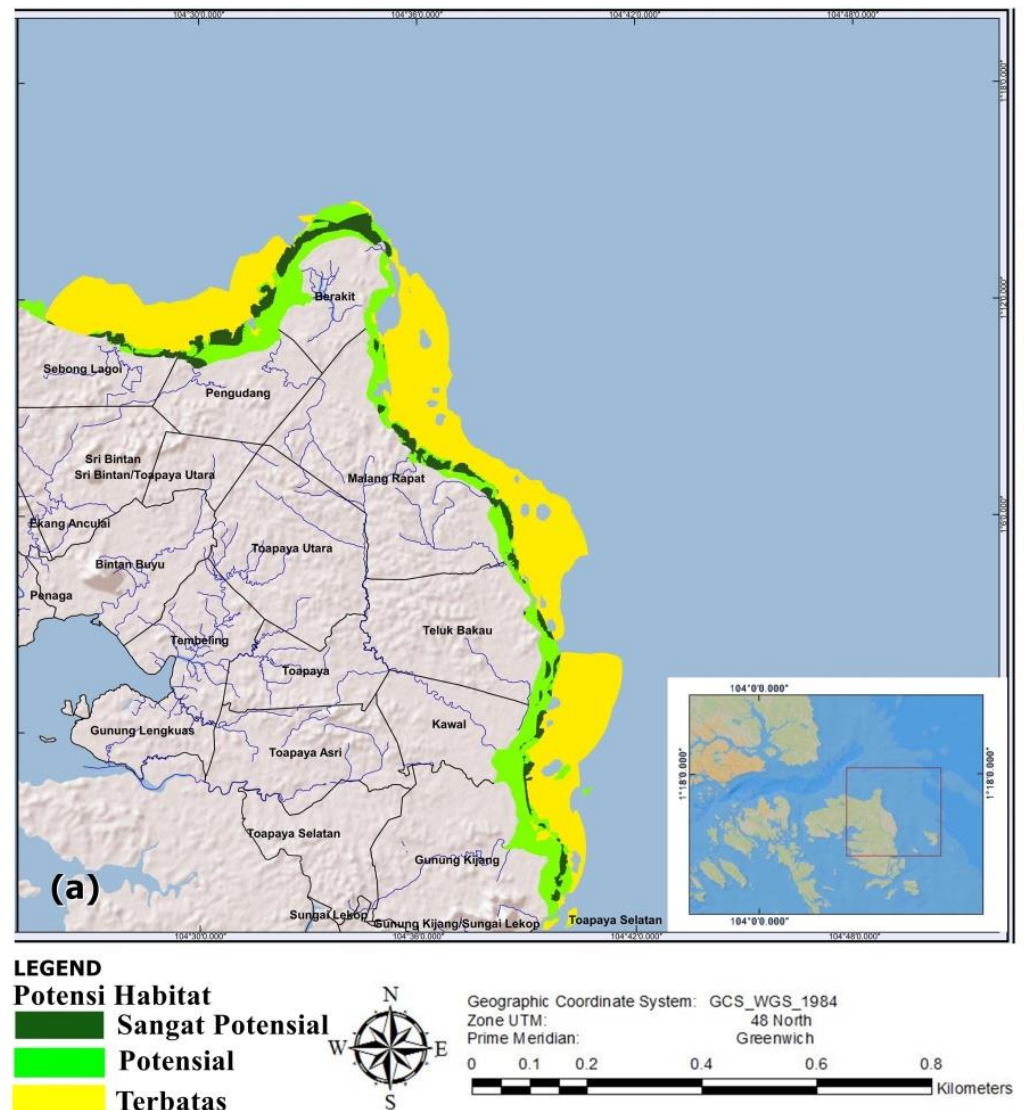

\section{Kontriusi Variabel Pemodelan}

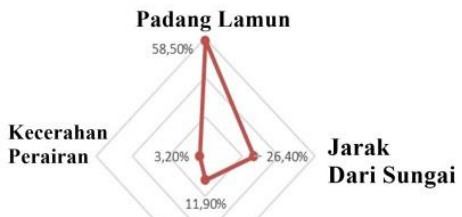

(b) Kedalaman Perairan

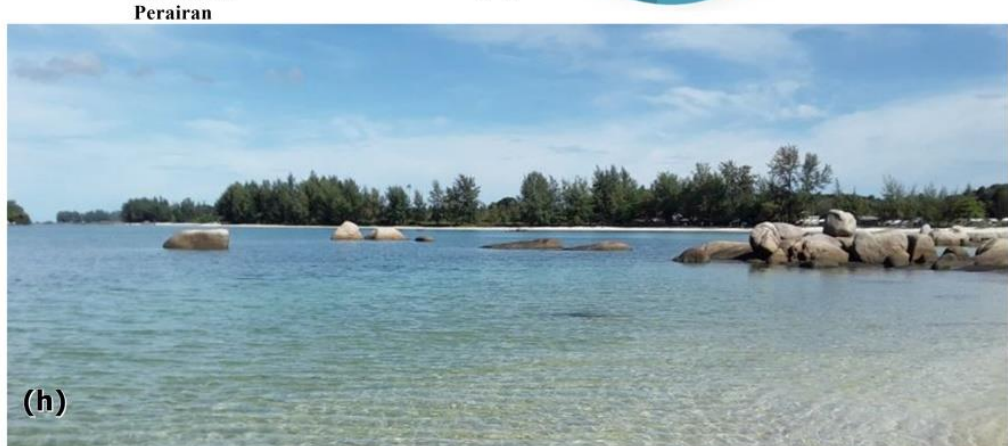

\section{Persentasi Potensi Habitat}

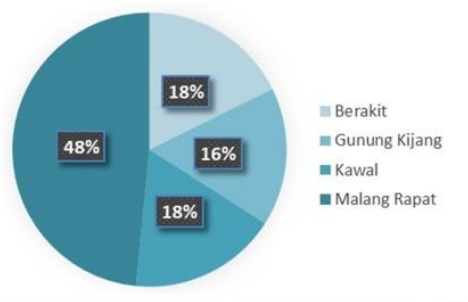

(c)
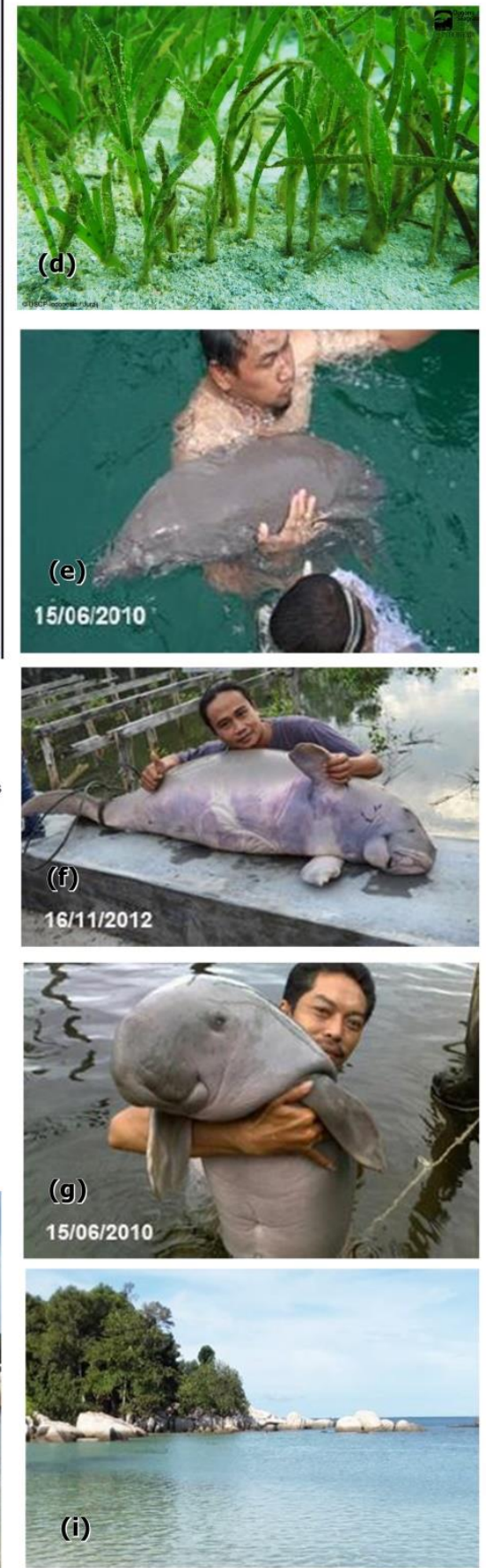

Gambar 4. (a) peta sebaran habitat dugong yang terbagi menjadi tiga kelompok yaitu sangat sangat potensial, potensial dan terbatas (b) persentase kontribusi variabel pemodelan habitat, (c) persentase habitat di setiap desa, (d) lamun vegetasi pemakan dugong, (e)(f)(g) dokumentasi perjumpaan dugong dari data BPSPL, (h)(i) dokumentasi observasi tahun 2020, di perairan Pulau Bintan yang menunjukkan lanskap perairan Bintan yang tenang dan bersih Pulau, banyak vegetasi lamun. 
Selanjutnya adalah distribusi spasial menunjukkan sebaran habitat dugong dapat dilihat pada Gambar 4 yang merupakan peta hasil pengolahan melalui software Maxent untuk mengetahui sebaran potensi habitat dugong di perairan Pulau Bintan. Untuk pemetaan habitat potensial dugong, kami kelompokkan menjadi 3 kategori, yaitu kawasan habitat sangat potensial, habitat potensial, habitat terbatas. Zona berwarna hijau gelap menujukkan area yang sangat berpotensi untuk habitat Dugong, dimana disini diyakini akan banyak perjumpaan dugong pada lokasi tersebut, sedangkan warna hijau muda menujukkan lokasi tersebut berpotensi sesuai artinya masih dimungkinan area ini menjadi habitat yang bisa mendukung keberlangsungan kehidupan satwa dugong dan yang berwarna kuning adalah habitat terbatas dengan kemungkinan keberadaan dungong juga sangat terbatas karena banyak variabel lingkungan yang tidak mendukung kehidupannya.

Setelah didapatkan hasil pengolahan algoritma melalui software Maxent, selanjutnya akan diolah kembali dengan Sistem Informasi Geografis (SIG). Dari hasil analisis Maxent yang diperoleh, yang kemudian dikelompokkan menjadi tiga kelas wilayah persebaran habitat potensial bagi dugong, yaitu potensi habitat terbatas, habitat potensial, dan habitat sangat potensial yang dibagi berdasarkan wilayah administrasi desa yang terdapat di beberapa perairan Pulau Bintan. Hasil Maximum Entropy habitat dugong hanya berupa peta sebaran spasial, hal ini hanya mudah dipahami oleh orang yang mengerti peta, namun tidak untuk masyarakat umum. Kami menyederhanakan data dengan membagi hasil analisis habitat ke dalam kelompok-kelompok kecil, sehingga mudah untuk memahami bagaimana persebaran masing-masing wilayah dan mudah untuk menggambarkan kepada masyarakat umum tentang keanekaragaman habitat dugong di Pulau Bintan. . Dari hasil sebaran, wilayah desa di beberapa perairan Pulau Bintan yang termasuk dalam wilayah potensial adalah empat desa, yaitu Desa Berakit, Desa Gunung Kijang, Desa Kawal, dan Desa Pertemuan Malang.

Tabel 1. Tabel potensi kawasan habitat dugong menurut wilayah administrasi desa di Pulau Bintan

\begin{tabular}{llllc}
\hline & & \multicolumn{2}{c}{ Luas Area (\%) } & \\
\cline { 3 - 4 } Desa & Terbatas & Potensial & $\begin{array}{c}\text { Sangat } \\
\text { Potensial }\end{array}$ \\
\hline . & Berakit & $24,5 \%$ & $53,9 \%$ & $21,6 \%$ \\
. & $45,3 \%$ & $48,5 \%$ & $6,2 \%$ \\
Gunung Kijang & $65,8 \%$ & $29,1 \%$ & $5,1 \%$ \\
. & Kawal & $77,9 \%$ & $14,6 \%$ & $7,5 \%$ \\
\hline
\end{tabular}

Sumber: Hasil analisis data penelitian, 2021

Tabel 1 di atas merupakan persentase luasan potensi habitat dugong. Desa Berakit memiliki habitat terbatas sekitar 24,5\%, habitat potensial 53,9\%, dan habitat sangat potensial 21,6\%. Desa Gunung Kijang memiliki habitat terbatas sekitar 45,3\%, habitat potensial 48,5\%, dan habitat sangat potensial 6,2. Desa Kawal memiliki habitat terbatas sekitar 65,8\%, habitat potensial 29,1\%, dan habitat sangat potensial 5,1\%. Sedangkan Desa Pertemuan Malang memiliki habitat terbatas sekitar 77,9\%, habitat potensial 14,6\%, dan habitat sangat potensial 7,5\%. Dari data luas wilayah perairan di beberapa desa di Pulau Bintan yang berpotensi dengan keberadaan dugong ini, Desa Berakit merupakan salah satu desa yang memiliki persentase dugong tertinggi dengan habitat yang sangat potensial yaitu 21,6\%. Data ini dikuatkan dengan wawancara yang telah dilakukan dengan masyarakat suku bahari di Berakit, Kabupaten Bintan Timur, yang mendapat informasi bahwa sebaran ikan dugong terdapat di wilayah sekitar perairan Desa Berakit.

Bahkan masyarakat Suku Laut di Desa Berakit sering mendapatkan ikan dugong yang tertangkap secara tidak sengaja, sebaran ikan ini berada di Utara Pulau Sumpat, sekitar Perairan Pantai Laut Lobam, dan Perairan Desa Berakit (BPSL Padang, 2019). Sedangkan pada diagram berikut (Gambar 2) untuk total luas kawasan potensi habitat dugong secara keseluruhan, Desa Pertemuan Malang merupakan desa yang memiliki potensi luas wilayah tertinggi sebesar $48 \%$, disusul oleh 
Desa Berakit dan Desa Kawal dengan total persentase sebesar 18\%, dan yang terakhir adalah Desa Gunung Kijang dengan total persentase 16\%.

Dalam pemodelan sebaran habitat Dugong yang diprediksi, perlu menggunakan variabel lingkungan, dimana nilai-nilai variabel lingkungan tersebut menjadi dasar estimasi pemodelan habitat. Variabel lingkungan digunakan dalam penelitian ini karena memiliki pengaruh terhadap sebaran dugong dugon di beberapa wilayah perairan Pulau Bintan. Variabel lingkungan meliputi tutupan lahan berupa vegetasi perairan (Lamun), kedalaman laut, dan sungai.

Tutupan lahan di sini berupa vegetasi air atau padang lamun yang merupakan penghasil utama dugong itu sendiri. Dugong menjadikan ekosistem lamun sebagai salah satu habitatnya yaitu sebagai tempat makan dan habitat bermain. Dugong sendiri juga menghabiskan $41 \%$ atau 10 jam aktivitasnya untuk makan di ekosistem lamun (Hodgson, 2004). Sebaran spasial landskap ekosistem yang dapat merujuk kepada peta tutupan lahan mampu merepresentasikan kondisi ekologis suatu wilayah (Rahman, 2020), dengan data tutupan lahan ini, kita dapat mengidentifikasi sebaran habitat dugong di sekitar perairan Pulau Bintan. Variabel lingkungan yang lainya berupa kedalaman laut memiliki pengaruh penting karena berhubungan langsung dengan keberadaan produsen utama dugong yaitu padang lamun. Pengukuran kedalam perairan dapat dilakukan dengan analisis citra satelit digital (Arifin, 2021). Dugong juga cenderung menyukai laut dengan ombak yang lebih tenang, karena memudahkan dugong untuk mencapai makanannya di dasar laut dan juga memudahkan dugong untuk berkembang biak. Selain itu, juga memudahkan bayi dugong berenang untuk mengambil udara ke permukaan laut. Parameter sungai juga menjadi faktor penting, karena jarak dari laut ke muara sungai juga mempengaruhi persebaran habitat dugong itu sendiri. Berdasarkan hasil penelitian sebelumnya, dugong lebih menyukai $\mathrm{pH}$ air yang lebih stabil dan tidak menyukai air tawar serta sedikit menyukai air payau.

Persentase pengaruh variabel lingkungan menunjukkan seberapa besar kontribusi pengaruh masing-masing parameter lingkungan yang menentukan potensi kawasan habitat dugong di beberapa perairan Pulau Bintan. Persentase ini dihasilkan karena didasarkan pada lokasi temuan hewan di lapangan dan studi literatur terkait habitat dugong. Diagram radar menunjukkan persentase kontribusi variabel lingkungan dalam penelitian ini. Ditemukan bahwa parameter vegetasi perairan yaitu padang lamun $(58,50 \%)$ menjadi parameter tertinggi, disusul sungai $(26,40 \%)$, kedalaman $(11,90)$, dan kecerahan air $(3,20 \%)$.

\section{Pembahasan}

Hasil penelitian ini memberikan bukti bahwa tutupan lahan padang lamun merupakan persentase terbesar di antara variabel lingkungan lainnya, karena semua koordinat temuan dugong yang diolah dalam software Maxent berada di sekitar padang lamun yang merupakan ekosistem penghasil dugong itu sendiri. Dugong memanfaatkan ekosistem lamun sebagai salah satu habitatnya, yaitu sebagai tempat makan dan habitat bermain. Hal ini relevan dengan pernyataan peneliti sebelumnya, karakteristik dugong akan menghabiskan $41 \%$ atau 10 jam aktivitasnya untuk makan di ekosistem lamun (Hodgson, 2004). Wilayah administrasi yang memiliki potensi habitat dugong di perairannya ternyata juga dialiri oleh beberapa sungai besar, yaitu Desa Gunung Kijang yang dialiri oleh Sungai Galang Batang, Desa Kawal yang dialiri oleh Sungai Kawal, dan Desa Berakit dan Desa Pertemuan Malang. dialiri oleh Sungai Beru yang jaraknya cukup jauh. Sungai ini merupakan salah satu faktor yang mempengaruhi aktivitas sehari-hari dugong, karena dugong lebih menyukai $\mathrm{pH}$ air yang lebih stabil dan tidak menyukai air tawar dan menyukai sedikit payau. - Sehingga air yang dialiri sungai lebih disukai oleh dugong. Kedalaman laut memiliki pengaruh penting karena berhubungan langsung dengan keberadaan produsen utama dugong yaitu padang lamun. Padang lamun umumnya tumbuh di perairan dangkal yang relatif tenang dengan dasar pasir, pasir berlumpur, lumpur, atau kerikil, yang selalu tergenang saat air surut. Anugerah (2015) menjelaskan bahwa selain memudahkan dugong untuk mencapai makanannya di dasar laut, parameter kedalaman laut juga memudahkan bayi dugong berenang untuk mengambil udara ke permukaan laut dan memudahkan berkembang biak. 
Dalam pemodelan spasial hubungan antar variabel memegang peranan penting dalam pemodelan ini akan merepresentasikan pengaruh suatu variabel kepada model spasial, terutama dalam pemodelan habitat atau ancaman ekosistem (Hidayat dan Hanif, 2020). Dari penelitian ini, kontribusi variabel lingkungan tersebut memegang peranan penting dalam menentukan habitat dugong di perairan, yang dengan pemanfaatan teknologi gespatial ini dapat disajikan secara matematis atau visual bagaimana interaksi antara ruang dan variabel lingkungan merupakan kondisi lingkungan. kehidupan dugong di pulau bintan. Temuan dari penelitian ini, baik sebaran habitat maupun variabel yang mempengaruhi, dapat menjadi pertimbangan besar dalam pengambilan keputusan pengelolaan kawasan konservasi laut di Pulau Bintan.

\section{KESIMPULAN}

Berdasarkan hasil analisis yang dilakukan bahwa variabel lingkungan yang mempengaruhi persebaran habitat dugong yaitu ekosistem lamun yang merupakan produsen utama yang dikonsumsi oleh dugong. Jarak dari sungai juga mempengaruhi persebaran habitat dugong, karena dugong lebih menyukai kandungan $\mathrm{pH}$ air yang lebih stabil. Sedangkan kedalaman laut yang mempengaruhi keberadaan padang lamun sebagai penghasil utama dugong. Sebaran potensi habitat dugong berdasarkan pemodelan Maxent, terletak di 4 kelurahan/desa yaitu Berakit, Gunung Kijang, Kawal, dan Malang Temu yang ditunjukkan dengan nilai mendekati 1, indeks potensi keberadaan habitat dugong. lebih sesuai ditunjukkan dengan warna hijau tua pada peta dan jika nilainya mendekati 0 maka indeks potensi habitat akan lebih rendah atau kurang sesuai, ditandai dengan warna hijau yang lebih terang. Dengan hasil penelitian ini dapat dijadikan rekomendasi area yang menjadi target konservasi ekosistem laut untuk menjaga keberlangsungan kehidupan satwa yang dilindungi di Negara Indonesia ini.

\section{REFERENSI}

Abbas E Ali, H Andrea, Cadenbach, and Ehsan Salimi. 2017. A Kullback-Leibler View of Maximum Entropy and Maximum Log-Probability Methods. Journal MDPI Entropy 2017, 19, 232; doi:10.3390/e19050232

Abidin, Z. K., et al. (2019). Predicting potential conflict areas of the Malayan sun bear (Helarctos malayanus) in Peninsular Malaysia using Maximum Entropy Model. Journal Mammal Study. The Mammal Society of Japan. Available at: https://bioone.org/journals/mammal- study/volume-44/issue-3/ms2018 - 0064/ Predicting- Potential- Conflict-Areas-of- the-Malayan- Sun- Bear- Helarctos/ 10.3106/ms2018-0064.short., 44.

Adnyana, W. (2016). Kajian Awal Sebaran Temporal dan Spasial Kejadian Dugong Terdampar di Indonesia. Jurnal Kedokteran Hewan, Hal 1-9.

Anggraeni, Fitriyah; Herandarudei, Sekar; Irawan , Andri; , Juraij; Kiswara, Wawan; Munandar, Erik; Sunnudin, Adriani; Tania, Casandra; Khalifa, Ali Muta. (2018). Survei dan Monitoring Dugong dan Lamun. Jakarta: Institut Teknologi Bandung (ITB) Press.

Arafat, A., Subhan, B., Sukandar, \& Utama, C. S. (2018). Distribusi Habitat Pakan Dugong dan Ancamannya di Pulau-pulau Kecil Indonesia. Journal of Fisheries and Marine Science, Vol 2, No. 2.

Ashari, I. H., Apriadi, T., Eka Fitri, N. H., Saputri, D., \& Susiana. (2018). Identifikasi Potensi Kearifan Lokal Masyarakat Pesisir Pulau Bintan dalam Upaya Konservasi Dugong (Dugong dugon, Muller 1776). Jurnal Manajemen Sumberdaya Perairan, Volume 1. Nomor 1. Halaman 28-36. 
Atapada, Zakarias; Hadinata, Syarif Yulius; Khaifin; Santiadji, Veda; Suprapti, Dwi; Tania, Casandra; Wijanarko, Tutus; , Juraji. (2017). Survey Dugong dan Habitat Lamun. Jakarta: World Wide Fund for Nature (WWF) Indonesia.

Arifin W, Febriandi, Hanif M, Triyatno, Mokhtar S E, Mutia E. 2021. Application of Empirical Bathymetry Method on Sentinel 2A for Measuring Water Depth of Maninjau Lake. EPI International Journal of Engineering. https://doi.org/10.25042/epi-ije.022021.01

Balai Pengelolaan Sumberdaya Pesisir dan Laut (BPSPL) Padang. 2019. Resume Habitat Dugong (Duyung) Di Pulau Bintan Kepulauan Riau. (Bahan: Satker Tanjung Pinang).

Baldwin, R. A. (2009). Use of Maximum Entropy Modeling in Wildlife Research. Journal of Maximum Entropy, 11, 854-866.

Bashit, N., Heriza, D., \& Sukmono, A. (2018). Analisis Perubahan Kualitas Perairan Danau Rawa Pening Periode 2013, 2015 dan 2017 dengan Menggunakan Data Citra Landsat 8 Multitemporal. Jurnal Geodesi Undip, Volume 7, Nomor 1, Tahun 2018, (ISSN : 2337$845 \mathrm{X})$.

Budianto, S., \& Hariyanto, T. (2017). Analisis Perubahan Konsentrasi Total Suspended (TSS) Dampak Bencana Lumpur Sidoarjo. Jurnal Teknik Geomatika ITS, Vol. 6, No. 1, (2017) ISSN: 2337-3539.

DSCP. (2017). Program Konservasi Dugong dan Lamun Indonesia. Jakarta: Dugong and Seagrass Conservation Project (DSCP) Indonesia.

Elith, J., Graham, C. H., \& dkk. (2006). Novel methods improve prediction of species' distributions from occurence data. Journal of Ecography, 29 : 129-151, 2006.

Gunawan, H., \& Prasetyo, L. B. (2013). Fragmentasi Hutan: Teori yang mendasari penataan ruang hutan menuju pembangunan berkelanjutan. Pusat Penelitian dan Pengembangan Konservasi dan Rehabilitasi Badan Penelitian dan Pengembangan Kehutanan Kementerian Kehutanan, 16610. ISBN: 978-602-1681-03-9.

Hanif M, Putra G B, Hidayat R A, Ramadan R. Ahyuni, Afriyadi, Jaafar W S, Hermon D, Mokhtar S E. 2021. Impact of Coastal Flood on Building, Infrastructure, and Community Adaptation in Bukit Bestari Tanjungpinang. Journal Gea Geografi UPI. 2021a. https://doi.org/10.17509/gea.v21i2.38911.

Hanif M, Hidayat R A, Rahman H Z, Wibisono H T, Nazar A, Ahyuni, Wilis R. 2021 b. Zonation of Conflict between Sun Bear (Helarctos Malayanus) - Human as an Effort Wildlife Conflict Mitigation. . Journal of Environmental Engineering and Studies, e-ISSN: 2582-3132. Volume-6, Issue-2 (May-August).

Hanif M, Putra G B, Nizam K, Rahman H Z, Nfrizal A Y. (2019). Multi Spectral Satellite Data to Investigate Land Expansion and Related to Micro Climate Change as Threat to The Environment. ournal IOP Conf. Series: Earth and Environmental Science, Volume. 303. doi: 10.1088/1755-1315/303/1/012030.

Hidayat R A and Hanif M. 2020. Spatial Modeling of The Threat of Damage to The Peatland Ecosystem In The Mainland of Bengkalis Regency, Riau Province. Journal Social Polites. Vol 20. Special Issue. No 2. doi: 10.33541/sp.v21i3.2249

Hidayat A R et, al. (2020) Modeling of Conservation Priority Zone for the Helmeted Hornbill (Rhinoplax Vigil) In Silokek Geopark Area, West Sumatra. Preprints. DOI 10.20944/preprints202009.0676.v1

Merow, C., Silander, J. A., \& Smith, M. J. (2013). A practical guide to Maxent for modeling species' distributions: what it does, and why inputs and settings matter. Journal of Ecography, 36: 1058-1069. 
Kementrian Kelautan dan Perikanan. 2016. PRELIMINARY FIELD SURVEY ON DUGONG AND SEAGRASS HABITAT Bintan, 22 - 27 August 2016. Laporan. Ministry of Marine Affairs and Fisheries. Research Center for Oceanography - LIPI. Bogor Agricultural University. WWF-Indonesia

Mirah Sjafrie, N. D. (2018). Kandungan Energi Lamun Desa Berakit dan Desa Pengudang Pulau Bintan untuk Mendukung Keberadaan. Jurnal Penelitian Oceanografi, Vol. 4 No. 2.

Nazeri, M. (2012). Predictive Modeling and Mapping of Malayan Sun Bear (Helarctos malayanus) Distribution Using Maximum Entropy. Available at: https://journals.plos.org/plosone/article?id=1 0.1371/journal.pone.0048104., PLoS ONE 7(10).

Nazeri, M. (2012). Predictive Modeling and Mapping of Malayan Sun Bear (Helarctos malayanus) Distribution Using Maximum Entropy. Available at: https://journals.plos.org/plosone/article?id=1 0.1371/journal.pone.0048104, 7 .

Rahman H, Triyatno, Hanif M, Indrayani P. 2020. Spatial Assessment of Landscape Structure Changes and Ecological Connectivity in Padang Pariaman. MAT Journal of Remote Sensing GIS and Technology, 6(2). Available at: https://www.researchgate. net/publication/342707817_Spatial_Assessm

Philips, S. J., \& Dudik, M. (2008). Modeling of species distributions with Maxent: New extensions and a comprehensive evaluation. Modeling of species distributions with Maxent: new extensions and a comprehensive evaluation , 161-175.

Prathama, R., Putra, R. D., \& Zulfikar, A. (2017). Pemetaan Sebaran Padang Lamun Menggunakan CItra Satelit Landsat 8 di Desa Malang Rapat Kecamatan Gunung Kijang Kabupaten Bintan. Jurnal Ilmu Kelautan dan Perikanan, Halaman 1-8.

Sampurno, R. M., \& Thoriq, A. (2016). Klasifikasi Tutupan Lahan Menggunakan Citra Landsat 8 Operational Land Imagery (OLI) di Kabupaten Sumedang (Land Cover Classification using Landsat 8 Operational Land Imager (OLI) Data in Sumedang Regency). Jurnal Teknotan, Vol. 10 No. 2 P - ISSN :1978-1067; E - ISSN : 2528-6285.

Wiseli, R. (2017). Strategi Pengelolaan Dugong (Dugong dugon) di Provinsi Kepulauan Bangka Belitung. Jurnal Sumberdaya Perairan, Volume 11 Nomor 1. 